\title{
CATALAN PRONOMINALIZATION AND INFORMATION STRUCTURE: THE ROLE OF PRIMARY ACCENT
}

\author{
MONTSERRAT FORCADELL
}

\begin{abstract}
Certain aspects of Catalan pronominalization cannot be described without taking into account how informational content is mapped onto sentence structure. In this paper, some data previously considered in the literature (mainly from Todolí's "Els pronoms") will be (re)analyzed considering the effects of information packaging articulation in Catalan in order to provide a more unified account. Information structure requirements are relevant for the analysis of the restrictions on pronominalization since, in Catalan, position in sentence structure reflects the pragmatic import of constituents. Viewing clitic binding as a result of a thematization procedure allows for a wider and more coherent approach to pronominalization, since proforms substitute not only for thematic material that is omitted but also for thematic material that is located in dislocated slots.
\end{abstract}

\section{INTRODUCTION}

Pronominalization is an operation by which thematic material in the sentence is substituted by a proform. Thematic material may be either omitted and replaced by the corresponding clitic, or placed in a peripheral, dislocated position in the structure, since in Catalan, thematic material may not appear clause-internally; it must occupy a dislocated position (Vallduví, The Informational Component, "L'oració"). Hence, the existence of marked positions in the sentence should be taken into account when tackling pronominalization data, since material placed in dislocated thematic positions will usually require the binding of a clitic in canonical position. Since Catalan shows direct mapping of the theme-rheme partition onto sentence structure, and prosody "is correlated with syntactic structure in an important way" (Vallduví, The Informational Component 105), the location of primary accent is vital when identifying right-dislocated phrases, although right-dislocation might not be the mirror image of left-dislocation structurally. ${ }^{1}$ Material in either detached position will have the same syntactic requirements as to clitic binding. Furthermore, whatever the formal nature of the structure underlying dislocation might be, which is beyond the scope of this paper, dislocated slots will encode thematic material. ${ }^{2}$

Pronominalization has not been tackled as a unified phenomenon which derives from the omission or the placement in a dislocated position of the pronominalizable 
linguistic material. Likewise, sentence structure has not been fully considered when dealing with clitic binding. Often clitic binding has been seen as an operation explained on other grounds, and the placement of constituents in sentence positions that are not the "common" (canonical) ones (i.e., in dislocated slots) has been seen as a stylistic device, not as the need to present linguistic material in specific structural configurations according to its (thematic) informational import.

Since the most exhaustive description of Catalan pronouns and pronominalization is that of Todoli's "Els pronoms," I will select certain data from her chapter on Catalan pronouns and try to account for them in the same light as will be done with Solà's "stylistic inversions" in the next section (i.e., from an information packaging perspective) to show that marked positions in the structure (i.e., leftand right-dislocation slots) need to be considered for a coherent analysis of the data. Structural positions reflect specific configurations which encode linguistic material according to its informational value. Since in Catalan there is such direct correlation between prosody and sentence structure, the position of primary accent will be crucial in describing pronominalization for those cases in which the pronominalized material is not omitted but located in a (thematic) right-dislocated position. Likewise, considering the existence of a (thematic) left-dislocated position will also clarify certain pronominalization behavior, as will be argued in this paper. I hope to show that the consideration of the mapping of information status onto the structure of sentences may provide the grounds for a more coherent description of pronominalization phenomena.

Hence, this paper does not aim at proposing a new theory on information structure in Catalan, neither at checking the validity of approaches such as Villalba (Syntax and Semantics), López (Derivational Syntax), or Feldhausen. The objective is to show that attention to thematic status of linguistic material in the sentence, which is correlated with specific (thematic) dislocated slots (Vallduví, The Informational Component, "L'oració"), will prove necessary when accounting for pronominalization of non-omitted thematic material in Catalan. The exact formal nature of the two dislocated positions (left- and right-dislocated slots) is beyond the scope of this paper (see footnote 1). What is relevant here is that dislocated (thematic) material might require the binding of a clitic in the clause.

This article is organized in three main parts: a) a brief overview of the treatment in the literature of pronominalization in relation to clitic binding (section 2 ); b) a sketch of the realization of the informational level in Catalan (section 3); and c) the reanalysis of two cases of pronominalization in relation to information structure: pronominalization and clitic doubling, and the pronominalization of postmodifiers (section 4). 


\section{OVERVIEW OF THE TREATMENT OF PRONOMINALIZATION IN RELATION TO INFORMATION STRUCTURE}

Badia (184-186) mentions that there might be a desplaçament ("displacement") of the material that the speaker wishes to highlight, which triggers the appearance of a weak pronoun in the clause in the "normal" place which that kind of material would usually occupy. For instance, according to Badia, in his example En Joan, l'han premiat pel seu comportament ("Joan has been rewarded for his behavior"), the clitic $l$ ' appears as the result of a what he calls "structural pleonasm" to fill in the gap left by the anteposat ("preposed") direct object en Joan. Hence, Badia's approach acknowledges the need for the dislocated material to bind a clitic in situ (i.e., clause-internally). However, he associates this desplaçament with the function of emphasis, which is contrary to the informative import of dislocated positions, since they are thematic by definition (Vallduví, The Informational Component). In fact, Badia borrows Fabra's consideration of clitic insertion as pleonasm, adding to it the notion of "emphasis."

In "Els pronoms," Todolí refers to the structure of dislocation to discuss some of the pronominalization examples offered in her comprehensive description of Catalan pronouns, but in dealing with certain data, which we will reanalyze in this paper, she fails to consider primary accent position, which is directly correlated with the marking of structural (dislocated) positions in the sentence. Placement of material in those positions might require clitic binding.

Solà (Sintaxi normativa) does approach pronominalization of material that is thematic but present in the structure taking into account the operation of dislocation and its consequent grammatical requirement, the binding of a clitic in canonical position. Hence, he considers a fair amount of controversial data and captures the relevance of the existence of dislocated positions when accounting for pronominalization. Solà (242-243) says that some of these controversial cases stem from Fabra's (292-300) indication to avoid pleonasms as much as possible, by which he established that when there was an inversió ("inversion") (i.e., a left-dislocation), the "inverted" material would bind a clitic only if that material was a complement, not an adjunct (in that case, not only should the pronoun be omitted but the inversion itself avoided). However, Fabra's definition of adjunct was too broad, and included elements that were also complements pronominalized by pronouns $h i$ and $e n / n e / n$ ', which usually correlate with adverbial phrases. ${ }^{3}$ All that, together with a poor treatment of the phenomenon, created confusion among writers, proofreaders and grammarians, who tried to avoid such "duplications" at all costs, resulting in a tendency to avoid the use of pronouns even in contexts where they were required. ${ }^{4}$

However, although Solà approaches pronominalization with a sound 
perspective of clitic binding as a grammatical effect of the structural (dislocated) position of pronominalized material, there is still a case that he regards as stylistic, which might be also explained from an information packaging perspective and its structural correlation in Catalan. When approaching duplicats pronominals ("pronominal duplicates") in general, Solà does not disregard either the pragmatic import of structural positions or the grammatical effects of specific sentence configurations; however, there is one case that he calls inversió estilistica ("stylistic inversion") (249), which seems to defy the grammatical requirement of dislocation.

Solà (249) claims that it must be admitted that there exist "stylistic inversions," which have a literary overtone for a certain effect, and neither present the characteristic pause of ordinary inversions (i.e., left-dislocations) nor trigger clitic binding. He points out that such inversions, as the ones reproduced here in (1a-c), occur with material that would be pronominalized (if it did pronominalize) by not only troublesome clitics en/ne/n' and hi but by the rest of pronouns as well. This, according to him, proves the existence of such "stylistic inversions." That is, the "inverted" phrase in such occurrences would correlate (if it pronominalized) not only with the pronouns that usually pronominalize adjuncts (which, as we have already mentioned, are heterogeneous as to clitic binding; see footnote 3), but also with those that pronominalize arguments.

(1) a. Tot aquest discurs he tret dels capitols, y actes de les mateixes Corts. (A. Bosch, Summari..., Perpinyà 1628, p. 327b.)

b. Molt fort ha d'ésser el motiu perquè alterem l'ordre d'un complement. (Fabra, Conversa 293.)

c. Però [...] si en la prosa actual trobem tan abundosament tota mena d'inversions [...]. (Fabra, Conversa 300.)

If adjunct pronominalization is troublesome due to its heterogeneity and laxity in some contexts, we might regard example (1c) as reflecting such lenity as to clitic binding. That is, the constituent that is considered to be "inverted" (en la prosa actual "in the current prose") is of the adverbial type, which may have triggered the cliticless utterance in (1c). Although the phrase en la prosa actual functions as an argument in that context, ${ }^{5}$ its locative nature might have favored the omission of the clitic. Heterogeneity of adjuncts and their laxity in the degree of clitic binding requirement, together with some semantic factors that also constrain adjunct pronominalization (see footnote 3) might have contributed to the interpretation of en la prosa actual as an adjunct rather than as an argument. Thus, it is not surprising that sentence $(1 \mathrm{c})$ is cliticless. ${ }^{6}$ Notice that placing the adjunct clauseinternally would render it narrow focus (Però [...] si trobem tan abundosament tota mena d'inversions en la prosa actual) (Forcadell, Information Packing 340-342), 
which seems to indicate that preverbal adjunct position is to be considered thematic and, therefore, left-dislocated.

Example (1a) is excerpted from a text that belongs to the beginning of the seventeenth century, in which other occurrences of word orderings uncommon from the current perspective may also be found. However, the "inverted" constituent in sentence ( $1 \mathrm{~b}$ ) is charged with a substantial force or emphasis. In fact, if that sentence was uttered, primary accent would necessarily fall on the word fort ("strong"), the last accentable item in the "inverted" constituent (molt fort "very strong"). Hence, that sentence presents focus preposing. In Catalan, following Vallduví (The Informational Component), a structure with focus preposing may be analyzed as presenting the accented material in canonical position, with the right-dislocation of the (deaccented) string following the item bearing primary accent. Therefore, the example in (1b) will abide to the grammatical rules of pronominalization since the predicative molt fort, being accented, remains in situ and, therefore, no clitic is to be bound. It seems, then, that "stylistic inversions" conform to Catalan information packaging requirements, and, since they remain in canonical position (i.e., are not "inverted"/ dislocated), they do not pronominalize.

\section{THE REALIZATION OF THE INFORMATIONAL LEVEL IN CATALAN}

The choice of the specific linguistic devices that speakers use to encode propositions is carried out at the informational level of the language. At that level, propositional content is divided into two parts (theme and rheme) according to the speaker's hypotheses about the listener's epistemic state. Hence, linguistic material that is considered to carry information known by the interlocutor is marked differently from material that is considered to be unknown or that will fill a void in the hearer's mental representation in relation to the current state of affairs (Chafe; Prince; Vallduví, The Informational Component). ${ }^{7}$ Speakers will distinguish material that encodes activated or recoverable information (either from the linguistic context, the physical situation or general shared knowledge between interlocutors), from new, non-activated informative material. That is, speakers will mark thematic and rhematic material differently with the choice of a specific linguistic strategy that will articulate that material accordingly. In this paper, the term theme will be used to refer to Prince's (Towards a Taxonomy) "inferable" and ("situationally" and "textually") "evoked" entities. Likewise, the term rheme will refer to Prince's "brand new" and "unused" entities; i.e. non-salient or non-activated entities without further distinction. 
To encode propositions that can be adequately decoded as to their informative value, languages have different means of presenting or structuring information by using syntactic, morphological or prosodic means, or a combination thereof. The prosodic pattern of Catalan is intimately associated with its syntactic structure since Catalan draws basically on its syntax to express the partition between theme and rheme. Thus, the informational level of the language is directly mapped onto sentence structure (Vallduví, The Informational Component, "Detachment"), whereas other languages such as English may reflect that partition mainly through prosody (Selkirk; Rochemont).

Since in Catalan prosody is strongly correlated with surface structure, its prosodic pattern is quite strict in terms of primary accent assignment. Following Vallduví (The Informational Component), in Catalan, the item that receives primary accent is always the last accentable element of the rheme. This element carrying the accent marks off the right-boundary of the clause. Thus, the deaccented linguistic material that follows is deemed, in pragmatic terms, as part of the theme, and, in syntactic terms, it is considered to fall outside the core clause (i.e., outside the lowest adjunct-free sentential domain), as illustrated by the brackets in B's reply in (2). ${ }^{8}$ The object la carta ("the letter") appears outside the rheme (Rh), in a deaccented phrase. It is right-dislocated and, therefore, it must accordingly comply with the syntactic requirement that is posed by its extraction from the clause: the binding of a clitic in canonical position to fulfill the syntactic subcategorization needs of the verb. ${ }^{9}$ Compare sentence (2B), which presents a right-dislocation, with the ungrammatical cliticless utterance in (3).

(2) (A: Ensenya'm la carta "Show me the letter")

B: $\left[\begin{array}{lll}N_{0} l_{i} & \text { TINC, }\end{array}\right]_{\mathrm{Rh}}$ la carta ${ }_{\mathrm{i}}$ not CL have.1SG the letter

"I don't have the letter"

(3) "No TINC la carta.

not have.1SG the letter

"I don't have the letter"

Dislocation can also go to the left, as shown in example (4). In Vallduví's model (The Informational Component, "Detachment"), the informational functions associated with left- and right-dislocation are not the same. Left-dislocated constituents function as links whereas right-dislocated constituents function as tails although both are part of the ground. However, in this paper, no distinction will be made as to the specific pragmatic function of thematic material since this would be beyond the scope of this work. What is relevant is that both positions are thematic. 
(4) La carta , $_{\text {no la }}$ TINC $]_{\mathrm{Rh}}$

CL letter not it.CL have.1SG

"I don't have the letter"

The dislocated constituents may be of a varied syntactic nature and there may be multiple dislocation. In that case, the constituents can be ordered freely since they are not restricted by the linear constraints that operate inside the sentence, as shown in the examples in (5), which present left- and right-dislocation of two phrases, els esquis "the skis" (object) and a Vielha "in Vielha" (adjunct). ${ }^{10}$

(5) (A: We could leave our skis in Vielha)

a. B: Els esquís ${ }_{i}$, a Vielha, no els ${ }_{i}$ hi $_{j}$ DEIXAREM.

the skis in Vielha not CL CL will.leave.1PL

b. B: A Vielha, els esquís, no els ${ }_{i}$ hi $_{j}$ DEIXAREM

in Vielha the skis not CL CL will.leave.1PL

c. B: No els ${ }_{i}$ hi $_{j}$ DEIXAREM, els esquís, a Vielha ${ }_{i}$.

not CL CL will.leave.1PL the skis in Vielha

d. B: No els hi $_{j}$ DEIXAREM, a Vielha $a_{j}$, els esquís. not CL CL will.leave.1PL in Vielha the skis

"We are not leaving our skis in Vielha"

Catalan syntax reflects the informational status of sentence constituents by placing thematic material in peripheral, dislocated positions. However, English, for instance, to mark pragmatic information usually resorts to a prosodic strategy that allows the placing of the primary accent on any element in situ that needs to be marked as the focus. See, for example, the sentence in (6), modeled on (2B) (No la TINC, la carta). Deaccented thematic material after primary accent need not be moved to a dislocated position in English; instead it may remain in canonical position as a result of in situ accent-shift.

(6) [I don't HAVE the letter]

While English also has the Catalan overt syntactic operation (i.e., dislocation: "I don't have it, the letter"), standard Catalan cannot resort to the English prosodic strategy (in situ accent-shift), as shown by ungrammatical (3) ("No TINC la carta), regardless of its actual function (it remains to be proved whether different structures are associated with different, or not exactly identical functions in different languages; English is commonly said to associate right-dislocation with the afterthought function, whereas thematic information is deaccented in situ as a result of accent-shift).

Whereas in Catalan there is an important correlation between surface structure and prosodic pattern, in English this association is apparently not so clear. ${ }^{11}$ The 
co-existence of different types of accents in the clause and the fact that primary accent may associate with partitions other than theme-rheme (informational structure) such as the "restrictor-nucleus" partition (quantificational structure), as Vallduví and Zacharski show, makes the prosodic picture in English quite complicated. Furthermore, while English sentences may present primary and secondary accents, Catalan may not. In Catalan sentences, only one accent is perceived with maximal prominence (Prieto, Entonació: models), marking sentence right-boundary.

Hence, in Vallduvís model, right-dislocations are not simply viewed as peripheral positions that allow for the repairing of a performance error (i.e., as afterthoughts), as seems to be mainly the case for English (Cowper; Geluykens), or just a way to encode a topic (Lambrecht; Givón; Gundel) but (also) as a syntactic resource of encoding an information instruction that marks the deaccented (dislocated) material as thematic. The general consensus about the material contained in a right-dislocated phrase is that it represents information that has been evoked, either explicitly or implicitly, in the prior text or situation; it is information already given or inferable, and it is believed to be in the hearer's knowledge store (Prince, "Towards a Taxonomy"); it is part of the theme; it must contain information that is discourse-old (not just hearer-old); that is, it must be assumed by the speaker to be salient or activated (Dryer) in the current communicative situation. ${ }^{12}$ Whatever the pragmatic import of dislocated constituents, there is general agreement on their thematic status. ${ }^{13}$

Although there are two detached positions (left- and right-dislocation) for the encoding of thematic material, right-dislocation in Catalan is easily identified since it is directly associated with primary accent position. That is, the deaccented phrase following primary accent will be right-dislocated and, therefore, might trigger clitic binding in the clause. Left-dislocated material will also trigger clitic binding but there might be no prosodic cue to mark off left-dislocated phrases (see footnote 15). Furthermore, subject left-dislocation is more difficult to ascertain on syntactic grounds only, since left-dislocated subjects will appear preverbally, as will subjects in canonical position, ${ }^{14}$ without binding a clitic in the clause (see footnote 9). Hence, the dislocated nature of preverbal subjects will have to be determined on pragmatic grounds since they may be marked off as left-dislocated by no prosodic cues either. ${ }^{15}$

Hence, since Catalan sentence structure is directly associated with prosody for the mapping the theme-rheme partition, we should take primary accent position into account when explaining pronominalization of either omitted or dislocated material, so that the pragmatic and consequent structural nature of pronominalized phrases is not overlooked. 


\section{SOME CASES OF PRONOMINALIZATION RELATED TO INFORMATION PACKAGING}

In "Els pronoms," Todolí gives a detailed description of the features and behavior of Catalan pronouns, and deals with prominalization by giving syntactic and semantic restrictions that govern this operation. However, some Catalan data seem to be better explained if we take into account position of linguistic material in the sentence as determined by prosody in the mapping of information content onto Catalan structure.

As we have just seen in section 3, Catalan isomorphism between prosody and surface structure results in a strict pattern in terms of primary accent assignment, which is, in turn, vital for determining which elements appear in situ, or rather in a detached, dislocated position, requiring clitic binding. In this section, I will present some of Todolís data from her exhaustive treatment of Catalan pronouns and pronominalization in "Els pronoms," and argue for an approach that takes structure into account, since it is directly linked to accent position.

\subsection{Clitic doubling or accent (mis)placement?}

In Catalan, there may be grammatical clitic duplication as a result of a morphological reflection of object agreement (Solà, Sintaxi normative; Todolí, "Doblament i represa," Els pronoms personals). This involves strong pronouns, inalienable objects and indirect objects, as shown in (7). Although clitic duplication is obligatory in certain contexts, as in (7a-b), in other cases it is optional, as in (7c). ${ }^{16}$ Furthermore, most of the sentences which are analyzed as presenting clitic duplication are, in fact, instances of pronominalization of dislocated material. That is, the clitic is correlated with linguistic material that is present in the structure but located in a position of dislocation to satisfy the requirements of the verb (Vallduví, The Informational Component; Forcadell and Vallduví). In that case, clitic duplication is only apparent, since it is triggered by the syntactic requirement posed by the extraction of a constituent from the clause. ${ }^{17}$

(7) a. *(Et) vaig convidar a TU.

"I invited you"

b. *(Li) van trencar la cama al JOAN/a ELL.

“They broke Joan's leg/his leg”

c. (Li) ho donaré a la MARIA/a ELLA.

"I will give it to Maria/to her"

When Todolí addresses constructions with clitic doubling in "Els pronoms," no reference is made as to which element in the utterance is marked with primary accent. That is, no reference is given as to the position that the doubled phrase 
occupies (i.e., whether it is in canonical position or right-dislocated after primary accent). For instance, Todolí ("Els pronoms" 1398) gives the examples in (8) to illustrate the phenomenon of clitic doubling with psychological verbs (doldre "upset, hurt"; agradar "like"; molestar "bother"; interessar "interest") and pseudoimpersonal verbs (passar, ocórrer "happen"; caldre, fer falta "be necessary"). However, if it is to be assumed that there is clitic doubling in the sentences in (8) (i.e., duplication of arguments in situ), we must also assume that primary accent is on the experiencer (a la Joana, a la Maria). That is, in order for the examples in (8) to display clitic doubling, the sentences must present no dislocation of the coreferential PPs a la Joana, a la Maria. However, with psychological and pseudoimpersonal verbs, in situ postverbal experiencers are marked as contrastive, as narrow focus (e.g., La cervesa no li agrada a la Maria, però sí al Joan "Maria doesn't like beer but Joan does") (Forcadell, Information Packing 326-345, "Subject Informational Status").

(8) a. La cervesa no li agrada a la Maria.

"Maria doesn't like beer"

b. No sé què li passa a la Joana.

"I don't know what's the matter with Joana"

In fact, Todolí herself claims that these examples are "more natural" with a left-dislocation in dialects with weak clitic doubling ("A la Joana no sé que li passa", "A la Maria no li agrada la cervesa"), which proves that she doesn't deem the (supposed) doubled constituents (a la Joana, a la Maria) as accented (i.e., as part of the rheme) being "more natural" in a left-dislocated thematic position. Thus, the non-contrastively marked counterparts of the sentences in (8) will present a dislocation, either to the left, as she claims, or to the right, as shown in (9), with primary accent on the verb, marking clause boundary and, therefore, triggering clitic binding.

(9) a. La cervesa no li AGRADA, a la Maria.

"Maria doesn't like beer"

b. No sé què li PASSA, a la Joana.

"I don't know what's with Joana"

It seems then that none of the sentences in (8) can be considered to present clitic doubling, since the clitic and the coreferential phrase do not co-occur in situ. Therefore, it might not be true that clitic doubling is obligatory or nearly obligatory in a majority of the contexts, as she claims for psychological and pseudo-impersonal verbs, since the constituents that correlate with the clitics, if they are thematic, will be located in a position of dislocation. 
Likewise, Todolí ("Els pronoms" 1400) also argues that clitic doubling is not obligatory in sentences with (meta "goal") indirect objects. According to her, in constructions with ditransitive verbs such as dir ("say, tell") and donar ("give"), clitic doubling is not obligatory but favored in Catalan dialects with strong clitic doubling if the indirect object is definite and the topic of the discourse, and the direct object is indefinite and rhematic. That is the reason, she argues, why the clitic is obligatory in example (10a) (Todolí, "Els pronoms" 1395), but optional in (10b). However, this description applies neither to declarative sentences, since indirect objects which are topics will be thematic and, therefore, will be located in a position of dislocation (e.g., Al director, li he donat l'ordinador nou "To the director, I have given him the new computer") nor to sentences of the interrogative type such as (10a) or (11), also given by Todolí ("Els pronoms" 1395), since the interrogative sentence type is quite restricted as to accent position (Prieto, Entonació: models; Forcadell, Information Packing \$4.7.1).

(10) a. ¿Què *(li) has explicat al director? ${ }^{18}$

"What have you told the director?"

b. Això no (li) ho expliques a ningú.

"You don't tell this to anyone"

(11) Què li ha semblat al director el nostre projecte?

"What did the director think of our project?"

The example in (10a) requires clitic binding, not, as she points out, because of the nature of the objects involved, but owing to the fact that the indirect object al director should be dislocated in a que-interrogative, as in example (12). Due to the restricted prosodic pattern of interrogatives in general and of què-interrogatives in particular (see above), dislocation applies to sentences with indefinite indirect objects as well, which tend to be rhematic. Contrast grammatical (13a), with an indefinite indirect object in a right-dislocation position, with ungrammatical (13b), with ungrammatical clitic duplication due to the lack of dislocation of the same indefinite object in that què-interrogative.

(12) Què li has EXPLICAT, al director?

"What did you explain to the director?"

(13) a. Què li EXPLICARIES, a un nen?

b." Què li explicaries a un NEN?

"What would you tell a kid?"

Hence, the accenting restriction imposed by què-interrogatives requires the deaccenting (and consequent dislocation) of the indirect object. In fact, the 
example in (11) should encode both the indirect and the direct object in dislocated slots (i.e., Que l'hi ha SEMBLAT, al director, el nostre projecte?).

Nevertheless, if we express the proposition in (12) in declarative form, the indirect object may appear either in situ (thus presenting clitic duplication) if it is rhematic, or right-dislocated if it is thematic, as illustrated in (14a-b), respectively. Hence, clitic doubling in (14a) is a morphological reflection of object agreement, allowing for the omission of the clitic (li) (Ho he explicat al director), whereas the clitic in example (14b) is a structural mark correlated with the dislocated indirect object, and therefore there is no clitic doubling.

(14) a. Li ho he explicat al director.

"I have explained it to the director"

b. Li ho he EXPLICAT, al director.

"I have explained it to the director"

Likewise, an indefinite indirect object will appear either clause-internally or in a dislocated position, according to its informative status, as shown in (15a) and (15b), respectively. In the case of (15b), being right-dislocated, the indirect object will necessarily bind a clitic. Notice that placing both objects to the right of the structure allows us to prove that they are (right-)dislocated, since they can be reordered, as shown in (15b-c).

(15) a. No (li) ho diguis mai a un NEN, això.

b. No *(li) ho diguis MAI, a un nen, això.

c. No "(li) ho diguis MAI, això, a un nen.

"Don't tell this a kid ever"

Now, the clitic duplication in (10b) above, reproduced in (16a) here, is due not simply to the indefinite status of the NP but to the idiosyncrasy of the indefinite NP ningú as being a universal negative quantifier. Being part of the negation, it could be omitted (Això no ho expliquis), but not deaccented, as in (16b). Furthermore, the universal positive counterpart of ningú (tothom "everybody") will not be possible as the positive counterpart of the statement in (16) without sounding awkward, regardless of its informational status, as shown in (17a-b); instead a non-universal NP will be in order as, for instance, la teva sogra "your mother-in-law" in (18a-b).

(16) a. Això, no (li) ho expliquis a ningú.

b. "Això, no li ho EXPLIQUIS, a ningú.

"Don't tell anybody"

(17) a. ?? Això, no (li) ho expliquis a tothom.

b. ???/"Això, no li ho EXPLIQUIS, a tothom.

"Don't tell this to everybody" 
(18) a. Això, no ho expliquis a la teva sogra/a ella.

b. Això, no li ho EXPLIQUIS, a la teva sogra/a ella.

"Don't tell your mother-in-law"

It seems then that, in Catalan, prosody is crucial when marking structural positions and, consequently, when considering the clitic as a) a mere morphological reflection of object agreement, or b) a requirement posed by the operation of dislocation. It would be desirable to ensure that the term clitic doubling is restricted to the former of the two cases.

\subsection{Pronominalization of postmodifiers: heads in situ (rather than in postverbal position)}

According to Todolí ("Els pronoms" 1379), the pronominalization of the head avions with clitic en/ne/n' in example (19) renders the sentence ungrammatical. She claims that dos $\varnothing$ (i.e., the specifier plus null head NP), which appears to the left of the verb han arribat "have arrived," must appear not only postverbally but in complement position as well. Thus, as shown in example (20), if we relocate the $\mathrm{NP}$ dos $\varnothing$ in a postverbal position, the sentence is fine.

(19) *Dels avions que van sortir a mitjanit, dos no n'han arribat encara.

"Two of the planes that took off at midnight haven't arrived yet"

(20) Dels avions que van sortir a mitjanit, no n'han arribat encara dos.

"Two of the planes that took off at midnight haven't arrived yet"

However, the ungrammaticality of example (19) should be again explained in relation to the distribution of linguistic material in the sentence according its informational import. Todolí is right when arguing that postverbal position is not sufficient, but that the NP must also appear in complement position (i.e., in canonical position); if the NP is dislocated, the result is ungrammatical, as shown in (21). However, this does not only affect postverbal position but preverbal as well. If the preverbal NP dos $\varnothing$ appears in canonical position, as in example (22), right-dislocating the material that follows, the result is also grammatical. ${ }^{19}$

(21) "Dels avions que van sortir a mitjanit, no n’han ARRIBAT, encara, dos.

(22) Dels avions que van sortir a mitjanit, DOS, no n'han arribat encara.

Hence, the ungrammaticality of (19) is not due to the preverbal position of the NP dos $\varnothing$, but rather to the placement of this NP in a position of left-dislocation. Likewise, the sentence in (21) is ungrammatical since the NP dos $\varnothing$ is right-dislocated. Therefore, although bare subjects of unaccusative verbs such as arribar "arrive" may bind a clitic, as grammatical (20) shows, when this 
subject is dislocated, clitic binding is prevented. That is, if the specifier dos appears in a detached position, it functions as the head of the NP and, therefore, no clitic is bound, as in (23a). However, if the specifier appears in situ, it functions as a partitive determiner and, therefore, the clitic is required $(23 \mathrm{~b}) .^{20}$

(23) a. ARRIBEN, dos (barcos).

b. N'arriben DOS, de barcos.

Thus, Todolís restriction has to do not with the postverbal location of the head, but its informative nature and, consequently, its structural position. If the head is treated as rhematic, it will appear in situ. Otherwise, it will occupy a thematic dislocated position.

Likewise, contrast the grammatical sentence in (24) (in which the left-dislocated postmodifier of the noun mostra "sample" binds clitic en in the clause) with the ungrammatical string in (25); the ungrammaticality of (25) does not lie in the preverbal position of the object mostra "sample" but in the left-dislocated position that mostra occupies, and, therefore, it is not its postmodifier (d'això "of this") the string that must bind a clitic in situ but the object mostra itself. This is proved by the specific clitic bound in grammatical (26), which is not en, the one that usually correlates with dislocated postmodifiers of nouns but $l a$, which correlates with dislocated (feminine) objects like mostra (see footnote 10).

(24) D'això, en tinc una MOSTRA.

"I have a sample of this"

(25) "D'això, una mostra, en TINC.

"I have a sample of this"

(26) D’això, una mostra, la TINC.

"I have a sample of this"

Hence, for a postmodifier to pronominalize, its NP head must appear clauseinternally. Preverbal objects, like una mostra in (26), are clearly dislocated. Thus, it is not their postmodifier d'aixo that binds a clitic but the dislocated head mostra itself. Therefore, the grammaticality of $(27 \mathrm{a}-\mathrm{b})$, for instance, lies in the canonical position of the quantifier tres "three." In example (27a), it is in postverbal canonical position. In (27b), it is also in situ followed by right-dislocated material. However, in ungrammatical (28a-b), the NP tres $\varnothing$ is in a position of left- and right-dislocation, respectively. Notice, likewise, that example (28a) would be grammatical if the clitic bound was les (instead of en/ne/n'), as shown in example (29). This proves that it is the tres $\varnothing \mathrm{NP}$ object that is dislocated, since it is this NP that is coreferential with the clitic les in the clause; not its postmodifier. 
(27) a. De les samarretes que em vaig comprar ahir, n'he tornat TRES.

b. De les samarretes que em vaig comprar ahir, TRES, n'he tornat.

"I've returned three of the T-shirts I bought yesterday"

(28) a. "De les samarretes que em vaig comprar ahir, tres, n'he TORNAT.

b. "De les samarretes que em vaig comprar ahir, n'he TORNAT, tres.

"I've returned three of the T-shirts I bought yesterday"

(29) De les samarretes que em vaig comprar ahir, tres, les he tornat.

Finally, Todolí ("Els pronoms" 1387) also argues that the sequence aquest gènere "this genre" in example (30) cannot pronominalize in en in the subordinate clause because its noun head (textos "texts") precedes the verb (són "are"). Again, els textos is not only preverbal but also left-dislocated, which prevents pronominalization. In fact, the right-dislocated counterpart of (30) in (31) would convey the same informational content, which proves that els textos is thematic. In fact, the presence of the sequence aquest gènere in the main clause (preceding the subordinate clause in which its referential head, els textos, is found) marks this head as thematic.

(30) *No coneixen aquest gènere, per bé que els textos en són abundants.

"They don't know this genre, although the texts abound"

(31) No coneixen aquest gènere, per bé que són ABUNDANTS, els textos.

"They don't know this genre, although the texts abound"

Hence, linguistic material will pronominalize according to its informational value and the position in the structure that it will consequently occupy. Information structure is relevant for the analysis of restrictions on pronominalization, since clause structure configuration reflects the discursive status of constituents through a specific word/constituent order, which, in turn, will present a specific prosodic pattern. In Catalan, material located in a dislocated position will be treated as thematic and will generally pronominalize since it will be clause-peripheral.

\section{CONCLUSION}

Some pronominalization restrictions cannot be accounted for leaving aside the informational import of the constituents that realize a proposition. Positions in the structure must be taken into account, since proforms substitute not only for thematic material that is omitted, but also for thematic material that is dislocated and, therefore, even though it remains in the structure, it is not able to satisfy the subcategorization requirements of the verb. 
In Catalan, informational content is directly mapped onto sentence structure. Syntax reflects the informational status of constituents, since positions in the sentence are pragmatically marked. Thematic material is generally encoded in peripheral (dislocated) phrases, whereas rhematic material will appear clauseinternally. Since prosody is directly associated with the structure of the sentence in the mapping of the theme-rheme partition, the identification of primary accent is vital in ascertaining right-dislocated slots when analyzing pronominalization. Even though left-dislocation precedes primary accent, and it might not be the formal mirror image of right-dislocation, identifying the effect of right-dislocation on pronominalization will help identify similar effects triggered by the material located on the left-hand peripheral side of the structure.

Viewing clitic binding as a result of a thematization procedure allows for a wider and more coherent approach to pronominalization. Instances of clitic duplication, for example, can only be identified adequately if sentence boundaries are also identified. Furthermore, the position of pronominalized material (or that of its head) as pre or postverbal is not sufficient to account for clitic binding, since there are two slots in the structure for each of the two positions (i.e., in situ pre and postverbal, and dislocated pre and postverbal), not just one. Hence, the description of pronominalization phenomena should be based on pragmatic grounds, relating to the (thematic) status of the replaced material and its consequent position in the structure, rather than on semantic or grammatical features that do not seem to apply to closely related data.

I hope to have shown that taking into account the articulation of pragmatic information in the sentence is crucial for a congruent description of pronominalization in data where pronouns substitute not for omitted material but for material that, being thematic, will appear clause-externally, unable to satisfy subcategorization requirement and, therefore, generally triggering clitic binding.

MONTSERRAT FORCADELL

Universitat de Barcelona

\section{NOTES}

1 As originally discussed for Catalan by Villalba ("Sobre la dislocació," "Right dislocation") and later revisited in Villalba (Syntax of Sentence Periphery, Syntax and Semantics), studies such as Cechetto; De Cat; Kayne; López; and Feldhausen also go against considering left-dislocation as the mirror image of right-dislocation from a formal viewpoint (Vallduví, The Informational Component), since right-dislocations are considered to be better analyzed in a clause-internal position (below TP/IP and above 
the VP). Furthermore, it is also commonly agreed that clitic left-dislocation (CLLD) and and clitic right-dislocation (CLRD) are functionally distinct too, as pointed out in Escandell-Vidal; Mayol ("Right Dislocation in Catalan"); and Villalba and Mayol, to cite works devoted to Catalan only.

2 The assumption here is not that all thematic material will necessarily occupy a dislocated position but that dislocated slots will encode thematic material, which might require clitic binding. See section 3 for an outline of the use made in this paper of the terms theme and rheme.

3 It is well-known that there are syntactic and semantic factors that will (dis)favor adjunct pronominalization, and that there is clitic weakening in some adjunct contexts as well. See, for instance, Todolí ("Els pronoms" 1404-1409) and Forcadell (Information Packing 99-104).

4 The exceptions to those overgeneralizations are Ferrater ("Gramàtiques") and Solà.

5 See Todolí ("Els pronoms" 1407) for discussion of similar examples with the verb trobar 'find', showing pronoun vacillation.

6 There is a similar example also from Solà (Sintaxi normative 248), which presents, according to him, vacillation in clitic binding as well:

Jordi Pujol va inaugurar ahir unes jornades sobre els Drets Culturals [...]. En aquest acte inaugural, Jordi Pujol, Ø va explicar que considera que [...]. (Avui, 6.II.1991, p. 34.)

The prepositional phrase (PP) En aquest acte inaugural "at this opening ceremony" is an adjunct of time, which does not bind a clitic, but its adverbial nature might have contributed to its listing among the controversial cases.

7 For an approach to information structure, see, among others, Erteshik-Shir (Information Structuring); and Zimmermann and Féry. As for Catalan, see also Vallduví ("Detachment”); Vallduví and Zacharski; Vallduví and Engdahl; Vallduví and Vilkuna; Mayol; Villalba ("Sobre la dislocació," Syntax and Semantics); and Feldhausen.

8 Capitals flag the item bearing primary accent (i.e., nuclear, pitch or sentence accent). Commas set off dislocated constituents.

9 In Catalan, not all dislocated material requires clitic binding. Subjects, for instance, do not, since, in the Catalan clitic paradigm, there is no coreferential clitic for subjects except for bare and quantified or partitive subjects of unaccusative verbs (e.g., En $n_{i}$ cauen (moltes), de pedres " (Lots of) stones fall/are falling”).

10 The clitics that are coreferential with the dislocated constituents are the following (taken from Vallduví, "Detachment" 576, n. 2): $/ / / / l o$ (and corresponding feminine and plural forms) pronominalizes determiner-headed objects; en/ne/n' pronominalizes determinerless objects and unaccusative subjects, some copular predicates, and PP complements headed by the preposition $d e$; ho pronominalizes tensed sentential complements, copular predicates, and the accusative demonstrative noun phrases (NPs) això "this" and allò "that." Clitic hi pronominalizes all prepositional complements other than those headed by de and can sometimes act as an indirect object clitic, replacing the default indirect object clitic li. Finally, in Catalan, bare NPs (also called partitive NPs), when dislocated, are accompanied by the preposition $d e$, which is optional in left-dislocations, but compulsory in right-dislocations (e.g., (De) gana, no en tinc molta vs No en tinc molta, "(de) gana "I'm not that hungry"). Clitics hi and en may also pronominalize adjuncts, although their behavior is heterogeneous (see n. 3). 
11 See, among others, Selkirk (Phonology) and Steedman ("Information Structure") for the relationship between prosodic structure and syntactic structure.

12 For those who consider right-dislocations a topic encoding strategy, there is also the question as to the nature of this topic. For instance, Ashby argues that "referents of right-detached constituents are more continuous or accessible topics than referents of left-detached constituents." See also Lambrecht; Ziv and Grosz; and, for Catalan, Mayol.

13 Except for the case of evaluative epithets, studied by Grosz and Ziv, and by Villalba ("Quantitative Comparative Study") for Catalan, where the dislocated referent is thematic, but the predication attached to it is clearly less so. Consider B's reply in Grosz and Ziv's example: A: I took my dog to the vet yesterday/B: He is getting unaffordable, the mangy old beast. As Villalba (1953) states, "omission of the dislocate would not yield to ungrammaticality, but it would entail the loss of the evaluative information." This (dislocated) epithet "transmits the speaker's attitude toward the referent."

14 Contrary to Vallduví ("Catalan as VOS," "L'oració"), who argues that preverbal subjects behave like complements and, therefore, when preverbal, they must occupy a left-dislocated slot, Forcadell ("Subject Informational Status") shows that preverbal subjects may also appear clause-internally in all-rheme sentences.

15 Astruc (Intonation) and Feldhausen (Sentential Form) show that Catalan clitic left-dislocations (CLLD) are accented, and Feldhausen also shows that CLLD is obligatorily separated from the main clause by an intermediate phrase or an intonation phrase boundary. However, since subjects do not generally correlate with a clitic in situ, such cues do not apply to subject left-dislocation and, therefore, they do not help identify the position of preverbal subjects as being in situ or left-dislocated

16 Notice that the absence of the clitic is grammatical (Ho donaré a la MARIA/a ELLA) although its presence seems to be favored by the pronominal object ( $i$ ho donaré a ELLA).

17 Ferrater; Solà (Estudis de sintaxi, A l'entorn); and Garolera are already suspicious of the notion of pleonasm (clitic duplication) and advocate revising it. Other works on clitic duplication in Catalan and other romance languages include Givón ("Topic, Pronoun”); Jaeggli; Bonet and Solà; Laca; Suñer; Solà (Lingüística i Normativa); Kayne; and Miller.

18 The question mark preceding the interrogative is Todolís.

19 Focusing on the quantifier "dos" might sound rather unnatural. However, we should take into account that this would be triggered by the need to perform a correction in a context where the value of that quantifier is, therefore, highly contrastive. Consider, for instance, B's reply in the following dialogue:

[A: Dels avions que van sortir a mitja nit no n'han arribat encara sis.]

B: Dels avions que van sortir a mitja nit, DOS, no n'han arribat encara.

20 Except for bare and quantified or partitive subjects of unaccusative verbs, as already pointed out in $\mathrm{n} .9$, subjects do not bind clitics (i), since there is a gap for subjects in the Catalan clitic paradigm. But dislocated subjects with an accented quantifier in situ will (ii), as will dislocated objects (iii).

(i) ("En) són la meva OBSESSIÓ, els barcos.

(ii) N'hi participaràn TRES, de nens.

(iii) En tinc TRES, de gats. 


\section{WORKS CITED}

Ashby, William J. "The Syntax, Pragmatics, and Socio-linguistics of Left- and Right-dislocations in French.” Lingua 75 (1988): 203-229.

Astruc, Lluïsa. The Intonation of Extra-Sentential Elements in Catalan and English. $\mathrm{PhD}$ Dissertation. University of Cambridge, 2005.

Badia i Margarit, Antoni M. Gramàtica de la llengua catalana. Descriptiva, normativa, diatòpica, diastràtica. Barcelona: Enciclopèdia Catalana, 1994.

Bel, Aurora. "Les funcions sintàctiques." Gramàtica del català contemporani. Eds. J. Solà, M.R. Lloret, J. Mascaró and M. Pérez Saldanya. Vol. 2. Barcelona: Empúries, 2002. 1075-1147.

Bonet, Sebastià, and Joan Solà. Sintaxi generativa catalana. Barcelona: Enciclopèdia Catalana, 1986.

Cechetto, Carlo. "A Comparative Analysis of Left and Right Dislocation in Romance." Studia Linguistica 53 (1999): 40-67.

Chafe, Wallace. "Givenness, Contrastiveness, Definiteness, Subjects, Topics and Point of View." Subject and Topic. Ed. C.N. Li. New York: Academic Press, 1976. 25-56.

Contreras, Heles. "On the Position of Subjects." Perspectives on Phrase Structure: Heads and Licensing. Ed. S.D. Rothstein. New York: Academic Press, 1991. 63-79.

Cowper, Elizabeth A. "Right-dislocation in Franco-Canadian." Chicago Linguistic Society 15 (1979):70-78.

De Cat, Cécile. French Dislocation. Interpretation, Syntax, Acquisition. Oxford: Oxford University Press, 2007.

Dryer, Matthew. "Focus, Pragmatic Presupposition, and Activated Propositions.” Journal of Pragmatics 26 (1996): 475-523.

Erteschik-Shir, Nomi. “The Syntax-focus Structure Interface.” The Limits of Syntax. Eds. P. Culicover and L. McNally. New York: Academic Press, 1998. 211-240.

- Information Structure. The Syntax-Discourse Interface. Oxford Surveys in Syntax and Morphology. Oxford and New York: Oxford University Press, 2007.

Escandell-Vidal, M. Victoria. "Differential Object Marking and Topicality: The Case of Balearic Catalan.” Studies in Language 33 (2009): 832-884.

Fabra, Pompeu. Converses filològiques, 10 vols. Barcelona: Barcino, 1954-1956.

Feldhausen, Ingo. Sentential Form and Prosodic Structure of Catalan. Linguistik Aktuell/ Linguistics Today. Amsterdam: John Benjamins, 2010.

Ferrater, Gabriel. "Gramàtiques per donar i per vendre.” Sobre el llenguatge. Ed. Joan Ferraté. Barcelona: Quaderns Crema, 1981. 13-21.

Forcadell, Montserrat. Information Packaging, Language Contact and Linguistic Change: Structural Calque in Catalan. PhD Dissertation. Barcelona: Universitat Pompeu Fabra, 2007.

- "Subject Informational Status and Word Order: Catalan as an SVO Language." Journal of Pragmatics, 53 (2013): 39-63.

- and Enric Vallduví. "Duplicación clítica: el caso catalán.” Actas del XVI Congreso Nacional de la Asociación Española de Lingüística Aplicada (AESLA) 1. Eds. F.J. Ruiz de Mendoza et al. Logroño: Universidad de La Rioja, 2000. 679-689.

Garolera, Narcís. “Una qüestió d'ordre: la disposició dels elements en l'oració.” Els Marges (1980): 18-19. 
Geluykens, Ronald. "Tails (Right-dislocations) as a Repair Mechanism in English Conversation." Getting One's Word into Line: On Word Order and Functional Grammar. Eds. J. Nuyts and G. De Schutter. Dordrecht: Foris, 1987. 119-129.

Givón, Talmy. "Topic, Pronoun, and Grammatical Agreement." Subject and Topic. Ed. C.N. Li. New York: Academic Press, 1976.

-. Topic Continuity in Discourse: Quantified Cross-Language Studies. Amsterdam: John Benjamins, 1983. 5-41.

Grosz, Barbara, and Yael Ziv. "Centering, Global Focus, and Right Dislocation.” Centering in Discourse. Eds. M. Walker, A. Joshi and E. Prince. Oxford: Oxford University Press, 1998. 39-51.

Gundel, Jeanette K. “Shared Knowledge and Topicality.” Journal of Pragmatics 9 (1985): 83-107.

Jaeggli, Osvaldo. Topics in Romance Syntax. Dordrecht: Foris, 1982.

Kayne, Richard. "Romance Clitics, Verb Movement, and PRO." Linguistic Inquiry, 22 (1991): 647-686.

Laca, Brenda. "Notes per a un estudi del pleonasme pronominal en català.” Miscel-lania Antoni M. Badia i Margarit, 5: Estudis dellengua iliteratura catalanes, XIII. Barcelona: Publicacions de L'Abadia de Montserrat, 1986. 65-88.

Lambrecht, Knud. Topic, Antitopic and Verb Agreement in Non-standard French. Amsterdam: John Benjamins, 1981.

Li, C.N., ed. Subject and Topic. New York: Academic Press, 1976

López, Luis. "Steps for a Well-adjusted Dislocation." Studia Linguistica 57(3) (2003): 193-231.

-. A Derivational Syntax for Information Structure. Oxford: Oxford University Press, 2009.

Mayol, Laia. “'Ho sabíeu, això?' La dislocació a la dreta en català.” Zeitschrift für Katalanistik 20 (2007): 221-238.

-. "Right-dislocation in Catalan: Its Discourse Function and Counterparts in English." Languages in Contrast, 7 (2007): 203-220.

Miller, Philip H. Clitics and Constituents in Phrase Structure Grammar. New York: Garland, 1992.

Prieto, Pilar. Notes sobre l'entonació dialectal del català: les oracions interrogatives absolutes. Barcelona: Publicacions de l'Abadia de Montserrat, 1998.

—. Entonació: models, teoria, mètodes. Barcelona: Ariel, 2002.

Prince, Ellen F. “Toward a Taxonomy of Given/New Information.” Radical Pragmatics. Ed. P. Cole. New York: Academic Press, 1981. 223-255.

-. "On the Syntactic Marking of Presupposed Open Propositions." Papers from the Parasession on Pragmatics and Grammatical Theory, Chicago Linguistic Society 22 (1986): 208-222.

Rochemont, Michael Focus in Generative Grammar. Amsterdam: John Benjamins, 1986.

Selkirk, Elisabeth O. Phonology and Syntax: The Relation between Sound and Structure. Cambridge, Mass: MIT Press, 1984.

Silva-Corvalán, Carmen. "Semantic and Pragmatic Factors in Syntactic Change." Historical Syntax. Ed. Jacek Fisiak. Amsterdam: Mouton, 1984.

Solà, Joan. Estudis de sintaxi catalana. 2 vols. Barcelona: Edicions 62, 1972-1973.

-. A l'entorn de la llengua. Barcelona: Laia, 1977. 
- Del català incorrecte al català correcte. Història dels criteris de correcció lingüística. Barcelona: Edicions 62, 1977.

-. Qüestions controvertides de sintaxi catalana. Barcelona: Edicions 62, 1987.

-. Lingüística i normativa. Barcelona: Empúries, 1987.

- Sintaxi normativa: estat de la qüestió. Barcelona: Empúries, 1994.

Suñer, Margarita. "The Role of Agreement in Clitic-doubled Constructions.” Natural Language and Linguistic Theory, 6 (1988): 391-434.

Steedman, Mark. "Information Structure and the Syntax-Phonology Interface." Linguistic Inquiry 31, 4 (2000): 649-689.

Todolí, Júlia. "Doblament i represa pronominal en català." Actes de l’XIè Col-loqui Internacional de Llengua $i$ Literatura Catalanes, III. Barcelona: Pubicacions de l'Abadia de Montserrat, 1996. 441-464.

-. Els pronoms personals. València: Universitat de València, 1998.

-. "Els pronoms." Gramàtica del català contemporani. Eds. J. Solà, M.R. Lloret, J. Mascaró and M. Pérez Saldanya. Vol. 2. Barcelona: Empúries, 2002. 1337-1433.

Vallduví, Enric. The Informational Component. New York: Garland, 1992.

- "Catalan as VOS: Evidence from Information Packaging." Linguistic Perspectives on the Romance Languages, Amsterdam Studies in the Theory and History of Linguistic Science IV: Current Issues in Linguistic Theory, Vol. 103. Eds. W.J. Ashby, M. Mithun, G. Perissinotto and E. Raposo. Amsterdam: John Benjamins, 1993. 335-350.

- "Detachment in Catalan and Information Packaging." Journal of Pragmatics 22 (1994): 573-601.

—. "L'oració com a unitat informativa." Gramàtica del català contemporani. Eds. J. Solà, M.R. Lloret, J. Mascaró and M. Pérez Saldanya. Vol. 2. Barcelona: Empúries, 2002. 1221-1279.

- and Ron Zacharski. "Accenting Phenomena, Association with Focus and the Recursiveness of Focus-ground." Proceedings of the 9th Amsterdam Colloquium. Institute for Logic, Language and Computation. Eds. P. Dekker, and M. Stokhof. University of Amsterdam, 1994. 683-702.

-, and Elisabet Engdahl. "The Linguistic Realization of Information Packaging." Linguistics 34 (1996): 459-519.

-, and Maria Vilkuna. "On Rheme and Kontrast." Syntax and Semantics 29: The limits of syntax. Eds. P.L. Culicover and L. McNally. New York: Academic Press, 1998. 79-108.

Villalba, Xavier. “Sobre la dislocació a la dreta.” Llengua \& Literatura 7 (1996): 209-234.

- "Right Dislocation Is Not Right Dislocation." Studies on the Syntax of Central Romance Languages. Eds. O. Fullana and F. Roca. Girona: Universitat de Girona, 1998. 227-241.

- The Syntax of Sentence Periphery. PhD Dissertation. Barcelona: Universitat Autònoma de Barcelona, 2000.

- The Syntax and Semantics of Dislocations in Catalan. Köln: Lambert Academic Publishing, 2009.

- "A Quantitative Comparative Study of Right-dislocation in Catalan and Spanish." Journal of Pragmatics 43 (2011): 1946-1961.

-, and Laia Mayol. "Right-dislocation in Catalan: Tails, Polarity and Activation." International Review of Pragmatics 5 (2013): 87-117. 
Zimmermann, Malte, and Caroline Féry, eds. Information Structure. Theoretical, Typological and Experimental Perspectives. Oxford: Oxford University Press, 2010.

Ziv, Yael, and Barbara Grosz "Right Dislocation and Attentional State." Proceedings of the Ninth Annual Conference of the Workshop on Discourse. Eds. R. Buchalla, and A. Mittwoch. Jerusalem: Israeli Association for Theoretical Linguistics. Akademon Press, 1994. 184-199. 